\title{
ANALISIS PEMAHAMAN KOGNITIF MATEMATIKA MATERI SUDUT MENGGUNAKAN VIDEO PEMBELAJARAN MATEMATIKA SISTEM DARING DI KELAS IV B SDN PINTUKISI
}

\author{
Dini Nuraeni ${ }^{1}$, Din Azwar Uswatun ${ }^{2}$, lis Nurasiah ${ }^{3}$ \\ 1,2,3 PGSD FKIP Universitas Muhammadiyah Sukabumi \\ 1dini025@ummi.ac.id, ${ }^{2}$ uswatun.din@gmail.com,3iisnurasiah@ummi.ac.id
}

\begin{abstract}
The purpose of this study is to describe the results the analysis the ability to understand cognitive mathematics in the material "angles" when using video learning with an online system in class IV B SDN Pintukisi Sukabumi City. The research method used is descriptive qualitative method. Data collection techniques used were interviews and documentation. The writer acts as an instrument for collecting data. Data analysis techniques used are according to Miles and Huberman which consists of data reduction, data display, and Conclusion Drawing/Verification. The research subjects used were grade IV B students in the 2019/2020 school year. The number of students is 20 people. The results showed how to understand mathematics in the angles material, 2 students got the highest grades and 12 students got grades less than KKM.The results revealed that the cognitive understanding ability of students in class IV B based on the first indicator can be categorized high, the second indicator is categorized high, and the third indicator can be said to be very low.
\end{abstract}

Keyword: Analysis, Cognitive Understanding, Mathematics

\begin{abstract}
ABSTRAK
Penelitian ini bertujuan untuk mendeskripsikan hasil analisis kemampuan pemahaman kognitif matematika pada materi "sudut" ketika menggunakan video pembelajaran dengan sistem daring di kelas IV B SDN Pintukisi Kota Sukabumi. Metode penelitian yang digunakan adalah metode kualitatif deskriptif. Teknik pengumpulan data yang digunakan adalah wawancara dan dokumentasi. Penulis bertindak sebagai instrumen pengumpul data. Teknik analisis data yang digunakan adalah menurut Miles dan Huberman yang terdiri dari reduksi data (data reduction), penyajian data (data display), dan Conclusion Drawing/Verification. Subjek penelitian yang digunakan adalah siswa kelas IV B tahun pelajaran 2019/2020. Jumlah siswa sebanyak 20 orang. Hasil penelitian menunjukkan bahwa kemampuan pemahaman kognitif matematika pada materi sudut, 2 orang siswa mendapatkan nilai tertinggi dan 12 orang siswa mendapatkan nilai kurang dari KKM. Hasil penelitian mengungkapkan bahwa kemampuan pemahaman kognitif matematika siswa kelas IV B berdasarkan indikator pertama dapat dikategorikan tinggi, indikator kedua dikategorikan tinggi,dan indikator ketiga dapat dikatakan sangat rendah.
\end{abstract}

Kata kunci: Analisis, Pemahaman Kognitif, Matematika 


\section{A. Pendahuluan}

Matematika merupakan suatu ilmu yang menjadi mata pelajaran di setiap jenjang pendidikan yang ada di Indonesia. Hampir dalam setiap aktivitas sehari-hari tanpa disadari pasti menggunakan matematika. Menurut Susanto (2014: 184) "bidang studi matematika diperlukan untuk proses perhitungan dan proses berpikir yang sangat dibutuhkan orang dalam menyelesaikan berbagai masalah". Oleh karena itu, matematika menjadi mata pelajaran yang paling penting untuk dikuasai setiap orang dimulai dari anak kecil hingga dewasa.

Menurut Unaenah dan Sumantri (2019: 107) dalam kurikulum 2013, tujuan pembelajaran matematika salah satunya adalah memiliki kemampuan faktual dan konseptual dalam pengetahuan. Oleh karena itu, hal ini sama artinya dengan salah satu pemahaman yang harus dikembangkan siswa yaitu memahami konsep matematika.

Berdasarkan keadaan saat ini, ketika dunia sedang mengalami pandemi Covid-19, sistem pembelajaran langsung tidak dapat berjalan seperti biasanya.
Berdasarkan hasil wawancara dengan guru kelas IV B SDN Pintukisi, pembelajaran matematika dilaksanakan dengan sistem daring dengan membagikan video pembelajaran kepada grup WhatsApp kelas IV B.

Definisi pemahaman menurut H. A. Susanto (2015: 27) "pemahaman merupakan kemampuan untuk menjelaskan pengetahuan/informasi yang telah diketahui dengan kata-kata sendiri." Sedangkan menurut Ahmad (2014: 35) pemahaman berasal dari kata paham yang memiliki beberapa arti yaitu, pengertian pengetahuan yang banyak, pendapat, pikiran, aliran atau pandangan, dan mengerti dengan benar. Maka pemahaman merupakan suatu kemampuan untuk memahami atau mengerti suatu hal yang dimaksud.

Menurut Jihad dan Haris (dalam Syarifah, 2017: 64) Indikator pemahaman untuk pembelajaran matematika adalah sebagai berikut:

1. Kemampuan mengklasifikasikan objek-objek menurut sifat-sifat tertentu

2. Kemampuan menggunakan, memanfaatkan, dan memilih prosedur atau operasi tertentu 
3. Kemampuan

mengaplikasikan

konsep atau algoritma pemecahan masalah

Istilah kognitif berasal dari kata cognition yang berarti pengertian atau mengerti. Maksud pengertian dalam area kognitif ini adalah perolehan, penataan, dan penggunaan pengetahuan.(Indrijati, 2016: 44). Sedangkan Menurut Basri (2018: 1) kognitif merupakan suatu kemampuan yang mengedepankan keterampilan berbasis otak dan diperlukan untuk melakukan tugas apapun mulai dari sederhana hingga kompleks. Maka dapat disimpulkan bahwa Kognitif merupakan keterampilan yang berbasis otak dan digunakan untuk menyelesaikan tugas apapun secara bertahap.

Menurut Heruman dalam (dalam Ginanjar, 2019: 21) Konsepkonsep pada kurikulum matematika di SD/MI dibagi menjadi tiga kelompok besar yaitu (1) Penanaman Konsep Dasar (Penanaman Konsep), (2) Pemahaman Konsep, (3) Pembinaan Keterampilan. Oleh karena itu, penyampaian materi matematika harus didasari pada konsep-konsep kurikulum matematika di sekolah dasar agar menjadi pembiasaan bagi siswa untuk memahami konsep dalam materi yang disampaikan.

Tujuan

pembelajaran

matematika menurut Peraturan Menteri Pendidikan Nasional No.22 tahun 2006 tentang standar isi (dalam Rostika \& Junita, 2017: 36) menyatakan bahwa "dalam kurikulum mata pelajaran matematika mulai jenjang sekolah dasar sampai sekolah menengah di dalamnya terdapat standar kompetensi, yang salah satu kompetensi dasarnya mengarahkan siswa untuk mampu menggunakan konsep-konsep matematika dalam menyelesaikan masalah."

Materi

pembelajaran

matematika yang dianalisis merupakan materi sudut. Sudut adalah daerah yang dibatasi dua garis lurus atau dua sinar yang dapat digambarkan sebagai pertemuan dua garis lurus (Amalia dan Wahyudi, 2019: 164). Sejalan dengan pendapat menurut Rohmatun (2019: 14) "sudut diartikan sebagai daerah yang dibatasi oleh dua ruas garis atau sinar garis yang bertemu pada satu titik pangkal pertemuan".

Pembelajaran dilaksanakan dengan membagikan video pembelajaran. Video pembelajaran 
merupakan media audio visual yang telah beredar digunakan dan diminati anak sekolah dasar mulai dari jenis video pengetahuan, informasi, musik dan cerita-cerita bersejarah yang bisa disajikan ketika pembelajaran (Busyaeri, Udin, dan Zaenudin, 2016: 118). Sedangkan menurut Agustianingsih (2015: 58) video pembelajaran merupakan salah satu media pembelajaran yang tidak tercantum dalam buku guru dan buku siswa, hal tersebut membuat siswa menjadi lebih tertarik dan membuat pembelajaran menjadi lebih efektif ketika digunakan sebagai media tambahan pada Kurikulum 2013.

Guru kelas membagikan video pembelajaran dengan sistem daring. Pembelajaran daring merupakan salah satu metode pembelajaran yang menggunakan jaringan internet (Mustofa, Chodzirin, dan Sayekti, 2019: 153). Sejalan dengan pendapat menurut Bilfaqih dan Qomarudin (2015: 5) yang mengemukakan bahwa pembelajaran daring merupakan pembelajaran yang dilakukan melalui jejaring web dengan setiap mata pelajarannya menyediakan materi dalam bentuk rekaman video atau slideshow dan tugas-tugas yang harus dikerjakan dalam batas waktu yang ditentukan. Maka pembelajaran daring merupakan suatu usaha pembelajaran yang dilakukan oleh guru dan siswa tetapi menggunakan jejaring web.

Berdasarkan latar belakang masalah yang telah dipaparkan, penulis ingin mengetahui pemahaman kognitif siswa dalam pembelajaran matematika pada materi sudut ketika pembelajaran dilaksanakan menggunakan video pembelajaran sistem daring. Maka dari itu, penulis menyusun rumusan masalah sebagai berikut. Bagaimana pemahaman kognitif siswa dalam pembelajaran matematika pada materi sudut menggunakan video pembelajaran matematika sistem daring di kelas IV B SDN Pintukisi?

Tujuan penelitian ini adalah menganalisis pemahaman kognitif siswa dalam pembelajaran matematika pada materi sudut menggunakan video pembelajaran matematika sistem daring di kelas IV B SDN Pintukisi. Manfaat yang diharapkan dari penelitian ini adalah bagi siswa, untuk meningkatkan kemampuan pemahaman siswa dalam pembelajaran dengan keadaan 
apapun. Kemudian bagi guru Untuk menambah pengetahuan tentang sistem pembelajaran yang harus dilakukan dalam keadaan yang tidak memungkinkan bertatap langsung dengan siswa. Adapun manfaat bagi sekolah yaitu Sebagai salah satu solusi untuk membuat sistem pembelajaran yang dapat mengembangkan pembelajaran di sekolah.

\section{B. Metode Penelitian}

Penelitian ini menggunakan jenis metode penelitian kualitatif deskriptif. Penulis tidak membuktikan atau menolak hipotesis yang telah direncanakan. Akan tetapi penulis mengolah data dan mengkaji permasalahan dalam bentuk deskripsi yaitu tidak dalam bentuk angka. Metode penelitian kualitatif penelitian kualitatif merupakan suatu penelitian yang hasilnya tidak diperoleh melalui prosedur statistik atau metode kuantifikasi yang lain (Anggito dan Setiawan, 2018: 8-9).

Waktu yang digunakan penulis untuk melaksanakan penelitian yaitu pada semester genap tahun ajaran 2019/2020. Penelitian dimulai ketika telah mendapatkan surat izin penelitian. Penulis melakukan penelitian di SDN Pintukisi yang berada di Jalan Siliwangi No.18, Kebonjati, Kecamatan Cikole Kota Sukabumi, Jawa Barat. Akan tetapi penelitian terhambat karena adanya pandemi Covid-19. Oleh karena itu penelitian dilaksanakan di tempat masing-masing menggunakan sistem daring.

Subjek dalam penelitian ini, penulis menggunakan Quota Sampling. Subjek yang diteliti merupakan kelompok yang sudah ditentukan sesuai dengan kuota kelas, yaitu pada kelas IV B Sekolah Dasar Negeri Pintukisi Kota Sukabumi tahun pelajaran 2019/2020. Jumlah siswa sebanyak 22 orang. Penulis tidak meneliti banyak subjek penelitian karena keterbatasan waktu dalam penelitian.

Penelitian ini menggunakan teknik pengumpulan data wawancara dan dokumentasi yang berisi data hasil pemahaman kognitif siswa beserta nilai siswa kelas IV B SDN Pintukisi pada pembelajaran matematika materi sudut. Pada wawancara ini pihak yang diwawancara diminta pendapat, dan ide-idenya sehingga penulis harus 
mendengarkan secara teliti dan mencatat apa yang diucapkan dan dikemukakan oleh pihak wawancara. Wawancara dilakukan dengan sistem dalam jaringan melalui aplikasi Whats App. Adapun kisi-kisi pedoman wawancara yang telah disusun oleh penulis adalah sebagai berikut:

Tabel 1. Kisi-kisi Pedoman Wawancara Guru

\begin{tabular}{|c|c|c|}
\hline No & Aspek & $\begin{array}{l}\text { No } \\
\text { Item }\end{array}$ \\
\hline 1. & Penerapan Kurikulum 2013 & 1 \\
\hline 2. & $\begin{array}{l}\text { Pemahaman kognitif } \\
\text { matematika di kelas IV.B }\end{array}$ & 2,3 \\
\hline 3. & $\begin{array}{lrr}\text { Pemahaman kognitif } & \text { siswa } \\
\text { pada materi sudut } & \text { dalam } \\
\text { penggunaan } & & \text { video } \\
\text { pembelajaran daring } & \end{array}$ & $4,5,6$ \\
\hline 4. & $\begin{array}{l}\text { Hambatan pembelajaran } \\
\text { matematika menggunakan } \\
\text { video pembelajaran sistem } \\
\text { daring }\end{array}$ & 7 \\
\hline 5. & $\begin{array}{l}\text { Upaya meningkatkan } \\
\text { pemahaman kognitif siswa }\end{array}$ & 8 \\
\hline
\end{tabular}

Dokumentasi pada penelitian

ini penulis meminta data hasil tes tentang pembelajaran matematika pada materi sudut beserta data nilai kepada guru kelas IV B SDN Pintukisi dalam bentuk foto. Penulis akan menganalisis bagaimana hasil pemahaman siswa berdasarkan hasil nilai yang didapatkan setiap siswa di kelas IV B. Data nilai siswa beserta hasil pengerjaan pemahaman konsep siswa dapat dikategorikan dalam tabel berikut:
Tabel 2. Kriteria Capaian Pemahaman Konitif Siswa

\begin{tabular}{cc}
\hline Tingkat Keberhasilan (\%) & Arti \\
\hline$>80 \%$ & Sangat tinggi \\
$60-79 \%$ & Tinggi \\
$40-59 \%$ & Sedang \\
$20-39 \%$ & Rendah \\
$<20 \%$ & Sangat rendah \\
\hline
\end{tabular}

(Sumber: Aqib, Diniati, Jaiyaroh, dan

Khotimah, 2014: 41)

Teknik analisis data yang digunakan pada penelitian ini adalah menurut Miles dan Huberman yang terdiri dari reduksi data (data reduction), penyajian data (data display), dan Conclusion Drawing/Verification. Tahap reduksi data merupakan kegiatan merangkum, memilih hal-hal yang pokok, memfokuskan pada hal-hal yang penting, kemudian mencari tema dan polanya hingga membuang yang tidak diperlukan (Sugiyono, 2015: 338). Oleh karena itu, penulis merangkum data yang didapatkan ketika wawancara dengan dokumentasi yaitu memfokuskan pada hal yang penting berdasarkan pemahaman kognitif siswa dan hambatan yang dihadapi ketika pembelajaran matematika menggunakan video pembelajaran sistem daring. Penyajian data dapat memudahkan penulis untuk memahami apa yang terjadi dengan 
disajikan dalam bentuk uraian singkat maupun jenis lain. Maka dari itu, penulis mendeskripsikan hasil pengambilan data dalam bentuk uraian. Pada tahap Conclusion Drawing/Verification, data yang diperoleh setelah dilakukan tahapan reduksi data dengan penyajian data, kemudian data tersebut disimpulkan.

\section{Hasil Penelitian dan Pembahasan}

Hasil wawancara dapat dideskripsikan sebagai berikut:

1. Penerapan Kurikulum 2013

Pelaksanaan Kurikulum 2013 di SDN Pintukisi sudah berjalan dengan baik dan lancar. Khususnya dalam pembelajaran matematika, penerapan Kurikulum 2013 pada pembelajaran matematika sudah sesuai dengan ketentuan kurikulum tersebut, yaitu menggunakan strategi pembelajaran sebagai acuan guru atau teknik ketika melaksanakan pembelajaran agar tepatnya sasaran pada pelaksanaan pembelajaran matematika. Alokasi waktu pembelajaran matematika pada saat pembelajaran langsung dengan pembelajaran daring masih sesuai dengan ketentuan pada Kurikulum 2013 yaitu 6 jam per minggu. Perbedaannya hanya terletak pada kesiapan orangtua dan siswa dalam mendapatkan materi dan ketika mengumpulkan tugas.

2. Pemahaman kognitif matematika di kelas IV.B

Sebagian besar siswa di kelas IV B dapat memahami konsep matematika dengan benar, namun ada juga beberapa siswa yang mengalami kesulitan, kendalanya adalah belum lancar membaca. Akan tetapi, keaktifan siswa ketika proses pembelajaran dapat dikatakan baik. Keaktifan juga terlihat ketika siswa berinteraksi dengan temannya maupun dengan guru.

Adapun perbedaan pemahaman kognitif siswa ketika pembelajaran dilaksanakan secara langsung dengan pembelajaran daring. Siswa yang mendapatkan peringkat 1-5 kemampuan pemahaman kognitif masih stabil tidak menurun. Akan tetapi untuk siswa yang lainnya terdapat perbedaan ketika pembelajaran langsung dengan pembelajaran daring. Siswa dapat memahami dengan baik ketika pembelajaran dilakukan langsung, sedangkan ketika pembelajaran daring menggunakan video, 
ditemukan banyak kendala, salah satunya ketika guru mendapat keluhan dari orangtua siswa terkait kesulitan dalam mengajarkan anak belajar di rumah. Selain itu ada orangtua yang tidak memiliki HandPhone Android, sehingga ketika pembelajaran daring dilakukan, siswa tidak mendapatkan materi dengan baik, namun ketika pembelajaran langsung tatap muka siswa tersebut memiliki potensi akademik yang baik.

3. Pemahaman Kognitif Siswa ada Materi Sudut dalam Penggunaan Video Pembelajaran Daring

Siswa keseluruhan dapat mengklasifikasi jenis sudut berdasarkan bentuknya. Akan tetapi ketika mengklasifikasi berdasarkan ukurannya, terdapat siswa yang masih keliru karena memang secara keseluruhan masih terdapat satu atau dua orang yang belum mampu mengklasifikasi dengan benar.

Banyak siswa yang dapat memilih cara yang tepat untuk menjawab soal-soal dalam materi sudut. Akan tetapi masih terdapat beberapa siswa yang memilih cara yang salah untuk menjawab soal.
Salah satu contoh kekeliruan siswa ketika mengukur sudut.

kemampuan siswa dalam menggunakan cara untuk menyelesaikan permasalahan soalsoal matematika pada materi sudut ketika menggunakan video pembelajaran sistem daring yaitu masih banyak siswa yang kurang mampu menggunakan cara untuk menyelesaikan masalah dalam soal materi sudut. Terdapat siswa yang mampu menggunakan cara untuk menyelesaikan soal dengan baik, kemudian ada pula siswa yang langsung menjawab hasil dari soal tanpa menjabarkan cara yang harus digunakan. Siswa juga masih kebingungan ketika mendapatkan soal dalam bentuk cerita.

4. Hambatan Pembelajaran Matematika menggunakan Video Pembelajaran Sistem Daring

Hambatan yang dihadapi selama proses pembelajaran matematika menggunakan video pembelajaran sistem daring cukup yang pertama adalah karena tidak dapat melakukan pembelajaran dengan tatap muka, sehingga membuat siswa sulit memahami materi. Selain itu hambatan terdapat 
pada siswa yang kurang berminat ketika pembelajaran dilakukan di rumah. Orangtua pun merasakan hal yang sama ketika mulai merasa kesulitan dalam mengajarkan anaknya di rumah. Kemudian kendala lain adalah akses internet (kuota) karena untuk menggunakan aplikasi WhatsApp dan mengunduh video di aplikasi tersebut membutuhkan akses internet yang banyak. Hambatan lain adalah orangtua yang tidak memiliki fasilitas HandPhone berbasis Android, sehingga membuat siswa tidak mendapatkan materi pembelajaran dengan baik, bahkan jarang mengumpulkan tugas. Sangat disayangkan karena siswa tersebut merupakan siswa dengan potensi akademik yang tinggi khususnya dalam pembelajaran matematika.

5. Upaya Meningkatkan Pemahaman Kognitif Siswa

Upaya yang dilakukan oleh guru diantaranya adalah selalu memberikan motivasi untuk siswa yang sedang melaksanakan pembelajaran daring di rumah masing-masing. Selain itu, dalam memberikan materi pembelajaran matematika, guru selalu menyajikan video pembelajaran dengan menarik, sehingga membuat minat belajar siswa meningkat dan membuat pemahaman siswa menjadi baik. Kemudian, guru memberikan waktu untuk bertanya jawab secara daring maupun langsung terkait dengan materi pembelajaran yang telah disampaikan dalam bentuk video. Setelah siswa selesai mengerjakan tugas, guru selalu memberikan apresiasi dalam bentuk gambar bintang, juga memberikan ucapan terimakasih kepada siswa yang telah menyelesaikan tugasnya.

Pada dokumentasi, penulis mendapatkan data nilai siswa ketika pembelajaran matematika pada materi sudut yang dilakukan dengan pembelajaran daring menggunakan video pembelajaran. Berdasarkan nilai yang diberikan oleh guru, dapat disajikan dalam bentuk tabel berikut:

Tabel 3 Kategori Nilai Pemahaman Kognitif Matematika Kelas IV B

\begin{tabular}{cc}
\hline Kategori & Jumlah \\
\hline Nilai Tertinggi & 100 \\
\hline Nilai Terendah & 50 \\
\hline Rata-rata & 7,3 \\
\hline$>$ KKM $(70)$ & $40 \%$ \\
\hline$<$ KKM (70) & $60 \%$ \\
\hline
\end{tabular}

Berdasarkan dokumentasi yang guru berikan, dari 20 sampel terlihat 2 siswa yang mendapatkan hasil 100 dan 6 siswa mendapatkan 
hasil nilai yang melampaui batas KKM.

Maka dapat dipersentasekan siswa yang mendapatkan nilai melebihi KKM adalah 40\%.Kemudian 12 siswa yang kurang dari KKM dengan persentase $60 \%$.

Berdasarkan hasil dokumentasi data nilai siswa yang guru berikan, maka dapat disimpulkan bahwa kemampuan pemahaman kognitif siswa masih rendah, karena masih banyak siswa yang mendapatkan nilai kurang dari KKM. Selain itu, dari data hasil pemahaman siswa yang guru berikan, masih terdapat 1 indikator yang belum siswa kuasai, yaitu pada indikator ketiga, kemampuan mengaplikasikan konsep atau algoritma pemecahan masalah, $\mathrm{Hal}$ tersebut membuktikan bahwa pemahaman siswa masih kurang. Sejalan dengan pembahasan yang didapatkan oleh Pujiati, Kanzunnudin, dan Wanabuliandari (2018: 39) pada penelitiannya yang menganalisis kemampuan pemahaman konsep matematika di kelas IV SDN 3 Gemulung, dalam pembahasan diungkapkan bahwa siswa belum mampu mengembangkan syarat yang diperlukan dalam menyelesaikan soal, sehingga menunjukkan bahwa siswa kurang menguasai pemahaman materi yang guru berikan.

Berdasarkan indikator yang digunakan, maka dapat dikategorikan kemampuan pemahaman kognitif matematika siswa di kelas IV B SDN Pintukisi dalam tabel berikut ini:

\section{Tabel 4 Capaian Indikator Pemahaman Kognitif}

\begin{tabular}{ccc}
\hline Indikator & $\begin{array}{c}\text { Tingkat } \\
\text { Keberhasilan } \\
\text { siswa }\end{array}$ & Arti \\
\hline $\begin{array}{c}\text { Kemampuan } \\
\text { mengklasifikasikan } \\
\text { objek-objek } \\
\text { menurut sifat-sifat } \\
\text { tertentu }\end{array}$ & $73 \%$ & Tinggi \\
\hline $\begin{array}{c}\text { Kemampuan } \\
\text { menggunakan, } \\
\text { memanfaatkan, } \\
\text { dan memilih } \\
\text { prosedur atau } \\
\text { operasi tertentu }\end{array}$ & $75 \%$ & Tinggi \\
\hline $\begin{array}{c}\text { Kemampuan } \\
\text { mengaplikasikan } \\
\text { konsep atau } \\
\text { algoritma } \\
\text { pemecahan } \\
\text { masalah }\end{array}$ & & \\
\hline
\end{tabular}

Berdasarkan tabel di atas, maka kemampuan pemahaman kognitif siswa kelas IV B pada materi sudut matematika ketika pembelajaran dilaksanakan menggunakan video pembelajaran dapat dideskripsikan sebagai berikut:

1. Kemampuan mengklasifikasikan objek-objek menurut sifat-sifat 
tertentu. Kemampuan tersebut dalam materi sudut pembelajaran matematika mengacu pada bagaimana siswa mengklasifikasikan jenis-jenis sudut berdasarkan bentuk dan ukurannya. Berdasarkan hasil penelitian, pada kelas IV.B SDN Pintukisi, kemampuan siswa cukup beragam dalam mengklasifikasikan jenis-jenis sudut berdasarkan bentuk dan ukurannya. Ketika guru memberikan soal dalam bentuk gambar jenis sudut, contoh sudut tumpul siswa dapat mengklasifikasi dengan baik, mereka dapat menjawab soal tersebut dengan benar, namun ketika guru memberikan gambar berbentuk bangun datar dan mengarahkan siswa untuk mengklasifikasi jenis sudut yang ada pada bangun datar tersebut, masih terdapat beberapa siswa yang kebingungan, sehingga masih ada siswa yang keliru dalam menjawab soal tersebut. Selain itu, dalam kemampuan mengklasifikasikan jenis sudut berdasarkan ukurannya, masih ada beberapa siswa yang keliru. Seperti halnya dalam soal yang diberikan guru, ketika guru memberikan soal "jenis sudut apakah yang memiliki ukuran $130^{\circ}$ ?" masih ada sebagian siswa yang kurang tepat dalam menjawab soal tersebut. Sejalan dengan penelitian yang dilakukan oleh Sari (2017: 48) pada penelitiannya yang bertujuan untuk memaparkan hasil pemahaman konsep matematika pada materi besar sudut ketika pembelajaran dilaksanakan menggunakan pendekatan PMRI. Pada indikator kemampuan mengklasifikasi objek menurut sifatsifat tertentu, hasil kemampuan siswa dipersentasekan sebanyak $71,5 \%$ dalam kaegori baik. Maka dari itu pemahaman siswa pada indikator tersebut sudah baik, namun masih membutuhkan bimbingan guru.

2. Kemampuan menggunakan, memanfaatkan, dan memilih prosedur atau operasi tertentu. Kemampuan ini merupakan bagaimana kemampuan siswa dalam memilih cara yang tepat untuk menyelesaikan soal yang memerlukan operasi hitung. Berdasarkan soal yang diberikan guru pada siswa kelas IV B SDN Pintukisi, terdapat beberapa pertanyaan yang membutuhkan operasi hitung dalam 
Pendas : Jurnal IImiah Pendidikan Dasar, ISSN Cetak : 2477-2143 ISSN Online : 2548-6950

Volume V Nomor 01, Juni 2020

penyelesaiannya. Contoh seperti "jika satu putaran sudut dibagi menjadi dua sama besar, maka besarnya adalah..." dalam soal tersebut siswa diarahkan untuk mencari bagaimana operasi hitung yang tepat untuk menemukan jawaban dari pertanyaan tersebut. Jawaban yang benar adalah, karena 1 putaran sudut berukuran $360^{\circ}$, sehingga ketika 1 putaran tersebut dibagi menjadi dua sama besar maka operasi hitung yang tepat adalah “ $\frac{1}{2} \times 360^{\circ}=180^{\circ}$ " dari 20 sampel, 16 siswa dapat menentukan operasi hitung dengan baik dan mendapatkan hasil yang tepat. Sedangkan 4 siswa masih keliru dalam menentukan operasi hitung untuk soal tersebut, mereka hanya menjawab soal tanpa mencantumkan operasi hitung yang tepat, namun jawabannya pun tetap belum tepat. Sejalan dengan penelitian yang dilakukan oleh Sari (2017: 49) pada penelitiannya yang bertujuan untuk memaparkan hasil pemahaman konsep matematika pada materi besar sudut ketika pembelajaran dilaksanakan menggunakan pendekatan PMRI.
Pada indikator kemampuan menggunakan, memanfaatkan dan memilih prosedur tertentu, kemampuan siswa mendapatkan hasil persentase $85 \%$ dengan kategori sangat baik. Sehingga dapat disimpulkan bahwa kebanyakan siswa telah mampu menguasai indikator tersebut.

3. Kemampuan mengaplikasikan konsep atau algoritma pemecahan masalah. Kemampuan ini yaitu bagaimana siswa menggunakan konsep yang diberikan guru dalam memecahkan masalah yang ada pada soal yang guru berikan. Contoh soal pemecahan masalah yang guru berikan adalah "Apabila sudut seperempat dibagi menjadi dua sama besar, maka sudut yang terbentuk masing-masing besarnya adalah..." guru mengarahkan siswa untuk menjawab soal tersebut. Berdasarkan 20 sampel yang didapatkan, terlihat 3 orang siswa yang dapat menyelesaikan soal tersebut dengan cara yang benar dan jawaban yang tepat, 17 orang sisanya masih belum tepat dalam menjawab soal tersebut. Jawaban 17 orang siswa cukup beragam, diantaranya ada yang mampu 
menggunakan cara yang benar, namun belum mampu dalam operasi hitungnya, sehingga jawabannya salah. Selain itu, ada pula siswa yang hanya menjawab langsung tanpa menjabarkan operasi hitungnya. Maka dari itu, dapat disimpulkan bahwa siswa di kelas IV.B masih kurang dalam mengaplikasikan konsep atau algoritma pemecahan masalah. Sejalan dengan penelitian yang dilakukan oleh Aida, Kusaeri, dan Hamdani (2017: 15) pada penelitiannya yang bertujuan untuk menganalisis

kemampuan pemahaman konsep matematis dan kemampuan pemecahan masalah matematis, pada kemampuan menyelesaikan

masalah matematika, siswa mendapatkan hasil persentase $7,14 \%$ dengan kategori sangat rendah. Oleh karena itu, masih banyak siswa yang belum menguasai indikator tersebut, sehingga membutuhkan bimbingan lebih dari guru.

\section{Kesimpulan}

Berdasarkan hasil penelitian yang dilakukan menggunakan metode kualitatif deskriptif dengan teknik wawancara dan dokumentasi, kemampuan pemahaman kognitif siswa kelas IV B SDN Pintukisi pada pembelajaran matematika materi sudut yang dilaksanakan dengan sistem daring menggunakan video pembelajaran dapat disimpulkan. Kesimpulan tersebut adalah pemahaman kognitif siswa kelas IV B SDN Pintukisi pada materi sudut dalam pembelajaran matematika berdasarkan indikator pertama dapat dikategorikan tinggi, indikator kedua dikategorikan tinggi, sedangkan indikator ke-3 dapat dikatakan sangat rendah ketika pembelajaran dilaksanakan dengan sistem daring menggunakan video pembelajaran.

Hal tersebut terbukti berdasarkan data nilai yang menunjukkan dari sampel 20 siswa, terilhat bahwa 2 orang siswa mendapatkan nilai 100, 6 orang siswa mendapatkan nilai melampui batas $\mathrm{KKM}$, dan sisanya 12 orang siswa mendapatkan nilai kurang dari KKM. Selain itu, berdasarkan hasil pemahaman siswa, menunjukkan bahwa dari 20 sampel hasil pemahaman siswa yang guru berikan, masih banyak siswa yang belum menguasai indikator ketiga yaitu 
kemampuan mengaplikasikan konsep atau algoritma pemecahan masalah. Berdasarkan 20 sampel, hanya 3 orang siswa yang mampu menguasai indikator tersebut dari materi sudut yang guru berikan. Oleh karena itu, dapat disimpulkan bahwa kemampuan pemahaman kognitif siswa dalam pembelajaran matematika materi sudut dapat dikatakan sangat rendah pada indikator ketiga.

Berdasarkan hasil penelitian yang didapatkan, penulis memberikan beberapa saran yaitu guru lebih memperhatikan metode pembelajaran yang dilakukan dengan sistem daring. Lebih baik jika pembelajaran dilaksanakan melalui video call, sehingga minat siswa dalam pembelajaran akan meningkat, karena seperti bertatap muka langsung bersama guru dan teman-teman yang lain. Ketika siswa belum memahami materi dapat bertanya dengan mengungkapkannya melalui ucapan, dan teman-teman yang lain dapat menyimak pertanyaannya, sehingga dapat menyimak juga jawaban yang guru berikan. Maka dari itu, pembelajaran seperti layaknya melaksanakan pembelajaran langsung di sekolah walaupun hanya dapat melihat dari layar telepon genggam.

\section{DAFTAR PUSTAKA}

Agustiningsih. (2015). Video Sebagai Alternatif Media Pembelajaran

Dalam Rangka Mendukung Keberhasilan Penerapan Kurikulum 2013 di Sekolah Dasar. PEDAGOGIA: Jurnal Pendidikan, 4(1), 50.

Ahmad. (2014). Upaya Meningkatkan

Pemahaman Konsep Pelajaran IPS Melalui Model Pembelajaran Picture. Jurnal Pendidikan, 1(2), 34-41.

Amalia, D., \& Wahyudi, I. (2019). Matematika 4 untuk Tingkat SD (1st ed.). Depok: DAR EL ILM LI AWLAD.

Anggito, A., \& Setiawan, J. (2018). Metode Penelitian Kualitatif (E. D. Lestari, ed.). Kabupaten Sukabumi: CV Jejak.

Aqib, Z., Jaiyaroh, S., Diniati, E., \& Khotimah, K. (2014). Penelitian Tindakan Kelas. Bandung: CV. Yrama Widya.

Basri, H. (2018). Kemampuan Kognitif Dalam Meningkatkan Efektivitas Pembelajaran IImu Sosial Bagi Siswa Sekolah Dasar. Jurnal Penelitian Pendidikan, 18(1), 1-9.

Bilfaqih, Y., \& Qomarudin, M. N. (2015). Esensi Pengembangan 
Pembalajaran Daring (1st ed.). Yogyakarta: DEEPUBLISH.

Busyaeri, A., Udin, T., \& Zaenudin, A. (2016). Pengaruh Penggunaan Video Pembelajaran Terhadap Peningkatan Hasil Belajar Mapel IPA Di MIN Kroya Cirebon. Al Ibtida: Jurnal Pendidikan Guru MI, 3(1), 116-137.

Ginanjar, A. Y. (2019). Pentingnya Penguasaan Konsep Matematika Dalam Pemecahan Masalah Matematika di SD. Jurnal Pendidikan Universitas Garut, 13(01), 17-25.

Indrijati, H. (2016). Psikologi Perkembangan dan Pendidikan Anak Usia Dini Sebuah Bunga Rampai (1st ed.). Jakarta: KENCANA.

Mustofa, M. I., Chodzirin, M., \& Sayekti, L. (2019). Formulasi Model Perkuliahan Daring Sebagai Upaya Menekan Disparitas Kualitas Perguruan Tinggi. In Walisongo Journal of Information Technology (Vol. 1).

Pujiati, P., Kanzunnudin, M., \& Wanabuliandari, S. (2018). Analisis Pemahaman Konsep Matematis Siswa Kelas IV SDN 3 Gemulung Pada Materi Pecahan. ANARGYA: Jurnal IImiah Pendidikan Matematika, 1(1), 3741.

Rohmatun, Y. (2019). Asyiknya Belajar Pengukuran Garis dan
Sudut (D. Supriyono \& U. Widuri, Eds.). Semarang: ALPARIN.

Rostika, D., \& Junita, H. (2017). Peningkatan Kemampuan Pemecahan Masalah Siswa Sd Dalam Pembelajaran Matematika Dengan Model Diskursus Multy Representation (Dmr). EduHumaniora / Jurnal Pendidikan Dasar, 9(1), 35-46.

Sugiyono. (2015). Metode Penelitian Pendidikan (Pendekatan Kuantitatif, Kualitatif, dan R\&D). Bandung: Alfabeta.

Susanto, A. (2014). Teori Belajar dan Pembelajaran di Sekolah Dasar (1st ed.). Jakarta: Kencana Prenamedia Group.

Susanto, H. A. (2015). Pemahaman Pemecahan Masalah Berdasar Gaya Kognitif (1st ed.). Yogyakarta: DEPUBLISH.

Syarifah, L. L. (2017). Analisis Kemampuan Pemahaman Matematis Pada Mata Kuliah Pembelajaran Matematika Sma li. Jurnal Penelitian Dan Pembelajaran Matematika, 10(2), 57-71.

Unaenah, E., \& Sumantri, M. S. (2019). Analisis Pemahaman Konsep Matematis Siswa Kelas 5 Sekolah Dasar Pada Materi Pecahan. Jurnal Basicedu, 3(1), 106-111. 